\title{
Development opportunities of islamic finance in Kazakhstan: world experience and perspectives
}

\author{
Zhanar Oralbaeva ${ }^{1, *}$, Orazgul Dzhakisheva ${ }^{1}$, Karlygash Kurbanova ${ }^{1}$, Assiya Naukanova ${ }^{1}$ \\ ${ }^{1}$ Al-Farabi Kazakh National University, al-Farabi Ave. 71, 050040 Almaty, Kazakhstan
}

\begin{abstract}
An increase in demand for alternative financial services contributes to the growing importance of Islamic finance for a part of the international financial market, which represents for Kazakhstan a viable and sustainable sphere of capital investment in times of crisis to diversify risks. The article reveals the features of functioning of Islamic banks, highlights the main tools of Islamic finance, highlights the development of Islamic finance in foreign countries, including Arab countries, European countries and the United States. The author analyzes the key stages of the development of Islamic finance in Kazakhstan and highlights the problems that impede its full implementation. The recommendations aimed at the development of Islamic instruments in the framework of the Kazakhstani economy are presented. In conclusion, it is concluded that the state is the main institution on whose actions the further functioning of Islamic finance in Kazakhstan depends.
\end{abstract}

\section{Introduction}

As a result of the global crisis of the financial system due to the collapse of the structured financial market, the investment community has significantly increased attention to the Islamic form of financing. In modern conditions, the Islamic finance segment on a global scale is one of the fastest growing: "against the backdrop of the ruin of speculative banks, the profit of Islamic institutions is steadily increasing by $15-20 \%$ per year, assets - by more than $20 \%$, and the annual turnover of world banking assets of the Islamic world by 2016 is estimated at $\$ 882$ billion". Nowadays more than 300 financial institutions and 250 borrowing funds in more than 75 countries are engaged in Islamic finance, 45 of these countries use Islamic finance regulation system [1].

Sufficiently intensive development of Islamic banking is caused by both increasing demand and significant accumulation of financial resources by Muslim countries. There is some evidence that the Islamic financial market continues to evolve, and one of them is the race of European and American countries for receiving investments from Arab countries. The relevance of Islamic banking for the development of the Kazakhstan economy is growing. The problems associated with the global financial markets make it necessary to search for new or strengthen existing sources of investment capital and increase return on investment. In addition, today Islamic banking operates in regions that are particularly significant for the domestic economy, namely in the countries of Transcaucasia and Central Asia.

\footnotetext{
* Corresponding author: oralbaeva_zhanar@mail.ru
} 
Nowadays, Islamic finance and Islamic banking is popularized in almost all regions of the world: North Africa, Southeast Asia, the CIS, Europe, America, and the Middle East. It should be said that Islamic finance is actively developing in such non-Islamic countries as Great Britain, France, and Switzerland. In addition to the countries of Europe, the USA, Canada, Australia, New Zealand and Japan are actively developed [2].

\section{Methods}

When writing the work, scientific methods were used, which are based on the requirements of an objective and comprehensive analysis of the development of Islamic finance in Kazakhstan and abroad. Research is carried out using a combination of methods of scientific knowledge, such as analysis, synthesis, induction, deduction, observation, comparison, classification, grouping, generalization. The research methods used are selected in accordance with the purpose and objectives of the article. Methods of analysis and synthesis have revealed the essence, theoretical aspects of Islamic finance, identify countries and banks where Islamic finance is best developed. These methods also helped to identify the main problems of the development of Islamic finance in Kazakhstan. The principle of classification and grouping made it possible to identify groups of banking systems based on the introduction of Islamic finance: for example, fully Islamic, mixed, with one or two Islamic banks. Induction and retention methods are used to evaluate the effectiveness of Islamic finance development in Kazakhstan and in the world. The generalization method was useful for obtaining general conclusions based on the studies. A comparative analysis made it possible to compare countries by the number of Islamic banks, the number of training organizations, and the ratings of Islamic banks by assets, capital, and share.

\section{Results and discussion}

The assets of Islamic financial organizations grow by $15-20 \%$ every year, and therefore the Islamic financial system is recognized as fast-growing. However, this area has appeared recently, and therefore occupies a small volume on the world market. According to world rating agencies, the assets of Islamic financial organizations amounted to more than 1.5 trillion. dollars'. Also, a large number of Muslims around the world is considered one of the favorable factors for the development of Islamic Finance. The global financial crisis of 2008 was the impetus for the rapid spread of Islamic Finance in the world.

In modern conditions, the global segment of Islamic finance is estimated at 1.2-2 trillion. dollars and is the fastest growing. All over the world, and not only in Muslim countries, financial institutions are opened that comply with Sharia economic principles.

The region where Islamic Finance is most developed is considered to be the Gulf countries. Islamic Finance accounts for about $60 \%$ of all assets of Islamic financial organizations here. Iran, Pakistan and other countries in this region are Islamized, so there are fully Islamic standards that all banks and financial organizations must comply with. Mixed financial systems are also distinguished, where banks of both types of financial systems coexist, both traditional and Islamic. Countries with this type of financial system include Malaysia, Indonesia, the UAE.

Iran ranks first in terms of Islamic finance industry in the world. Assets of the Islamic financial system of Iran at the end of 2018 amounted to 518 billion dollars. In Saudi Arabia, Islamic bank assets totaled $\$ 252$ billion. Here, Islamic banking assets account for more than $50 \%$ of all banking system assets. In other countries of the Islamic financial industry, namely in the UAE, Kuwait and Qatar, the assets of Islamic financial organizations amounted to 98, 84 and 56 billion dollars. This can be seen in Figure 1. 


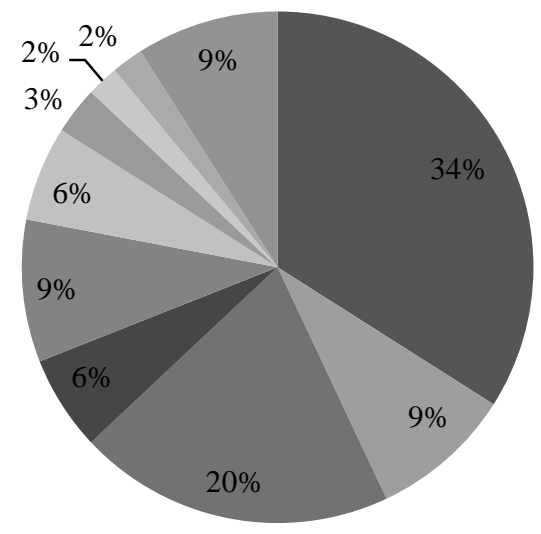

- Iran
- UAE
- Saudi Arabia
- Kuwait
- Malaysia
Qatar
- Turkey
- Bangladesh
- Indonesia
- Others

Fig. 1. Share of Islamic Finance in the world [2].

Malaysia is a leader in the Islamic finance market in Southeast Asia. Assets of the Islamic financial market amount to more than 180 billion dollars. Every year, Islamic financial assets grow by an average of $18.6 \%$, Islamic financial banking assets - by $9.3 \%$ over the past ten years. The second largest asset in Southeast Asia is Indonesia. Its assets amount to about 28 billion dollars, and they grow by about $40 \%$ every year [5].

Clients of Islamic financial organizations are all people, regardless of religion, country, or other factors. But in most cases, they are Muslims. The Muslim population today is about 2 billion people. However, countries in Europe, America, and Australia are also interested in the products and services of Islamic banks. in 1978, the world's first Islamic financial house was opened. Major global banks such as HSBC, Deutsche Bank, Calyon, Citibank, Standard Chartered, BNP Paribas, ING bank, Chaise Manhattan Bank, Goldman Sachs, the Nomura Securities, JP Morgan, Lloyds TSD and others are opening Islamic Windows to Finance individuals and businesses in their countries.

Table 1. The largest banks of CCASG [2].

\begin{tabular}{|c|c|c|c|c|c|c|c|}
\hline Name of the bank & Country & 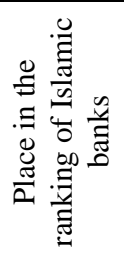 & 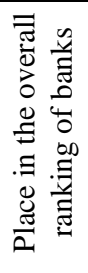 & 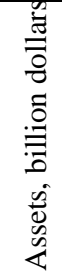 & 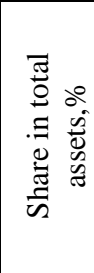 & 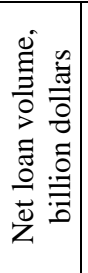 & 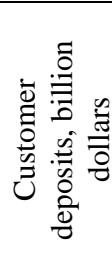 \\
\hline Al Rajhi Bank & Saudi Arabia & 1 & 5 & 71 & 22.5 & 46 & 59 \\
\hline Kuwait Finance House & Kuwait & 2 & 8 & 52 & 16.5 & 30 & 33 \\
\hline Dubai Islamic Bank & UAE & 3 & 17 & 26 & 8.2 & 15 & 18 \\
\hline Abu Dhabi Islamic Bank & UAE & 4 & 20 & 23 & 7.3 & 14 & 17 \\
\hline Qatar Islamic Bank (S. A.Q) & Qatar & 5 & 25 & 20 & 6.3 & 12 & 12 \\
\hline $\begin{array}{l}\text { Al Baraka Banking Group } \\
\text { B.S.C. }\end{array}$ & Bahrain & 6 & 26 & 19 & 6.0 & 12 & 15 \\
\hline Masraf Al Rayan & Qatar & 7 & 29 & 17 & 5.4 & 12 & 12 \\
\hline Bank Alinma & Saudi Arabia & 8 & 32 & 14 & 4.4 & 10 & 9 \\
\hline
\end{tabular}




\begin{tabular}{|l|l|c|c|c|c|c|c|}
\hline Bank Aljazira & Saudi Arabia & 9 & 33 & 14 & 4.4 & 8 & 11 \\
\hline Emirates Islamic Bank PJSC & UAE & 10 & 35 & 10 & 3.2 & 5 & 7 \\
\hline Ahli United Bank B.S.C. & Kuwait & 11 & 36 & 9 & 2.8 & 6 & 6 \\
\hline $\begin{array}{l}\text { Al Hilal Bank PJSC } \\
\begin{array}{l}\text { Qatar International Islamic } \\
\text { Bank }\end{array}\end{array}$ & QAE & 12 & 37 & 9 & 2.8 & 6 & 7 \\
\hline Barwa Bank P.Q.S.C. & 13 & 38 & 8 & 2.5 & 4 & 5 \\
\hline Boubyan Bank K.S.C. & Quar & 14 & 39 & 7 & 2.2 & 4 & 4 \\
\hline Sharjah Islamic Bank & UAE & 15 & 40 & 7 & 2.2 & 5 & 5 \\
\hline Noor Islamic Bank P.J.S.C. & UAE & 17 & 41 & 5 & 1.6 & 3 & 3 \\
\hline Total & & & & 316 & 100.0 & 195 & 227 \\
\hline
\end{tabular}

Islamic Finance in the United Kingdom. The United Kingdom has, for over thirty years, been a leading voice in the development of Islamic Finance. Islamic Finance first came to the UK in the 1980s, with the introduction of Murabaha transactions. The first UK Islamic bank, Al Baraka International, launched in 1982. This was followed by the growth of bespoke Sharia-compliant products in trade finance, leasing and project finance [7].

Concurrently, the offer of retail Islamic Finance services has increased substantially, providing choice to more than 2.5 million Muslims resident in the UK. At the present, there are five fully Sharia-compliant banks in the UK (Abu Dhabi Islamic Bank, Al Rayan Bank, Bank of London and The Middle East, Gatehouse Bank, QIB UK), with twenty institutions offering Islamic Finance services. To service this growing industry, a wide scale program of professional education and training in Islamic Finance developed. At present, four professional institutes and nearly 70 universities and business schools offer qualifications in Islamic Finance. The Islamic Bond (Sukuk) market in the UK started in 2007, and has continued to grow. By 2015, 57 Sukuk had been listed on the London Stock Exchange, with a total value of $\$ 51 \mathrm{bn}$ [8]. In 2014, the United Kingdom Government became the first Western government to issue sovereign Sukuk, over 11 times oversubscribed. London is the largest Islamic Finance center outside of the Muslim world.

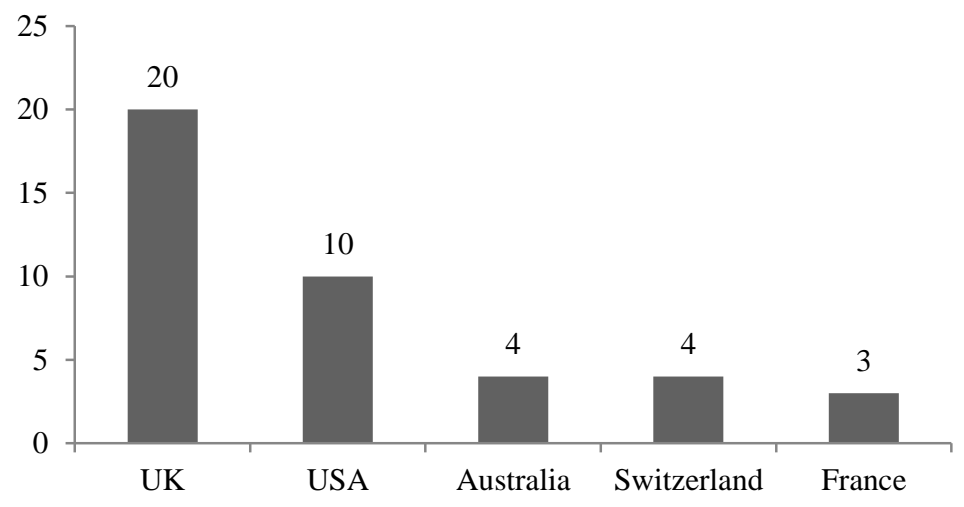

Fig. 2. Islamic banks in Western countries [9].

Islamic finance plays a significant role in infrastructure development in the UK. This includes development finance for The Shard, Battersea Power Station regeneration, London Gateway, the Olympic Village and the redevelopment of Chelsea Barracks. Over 6,500 homes in the North West and the Midlands are currently being financed by a $£ 700$ million investment by Gatehouse Bank, a fully Sharia-compliant bank [8]. 


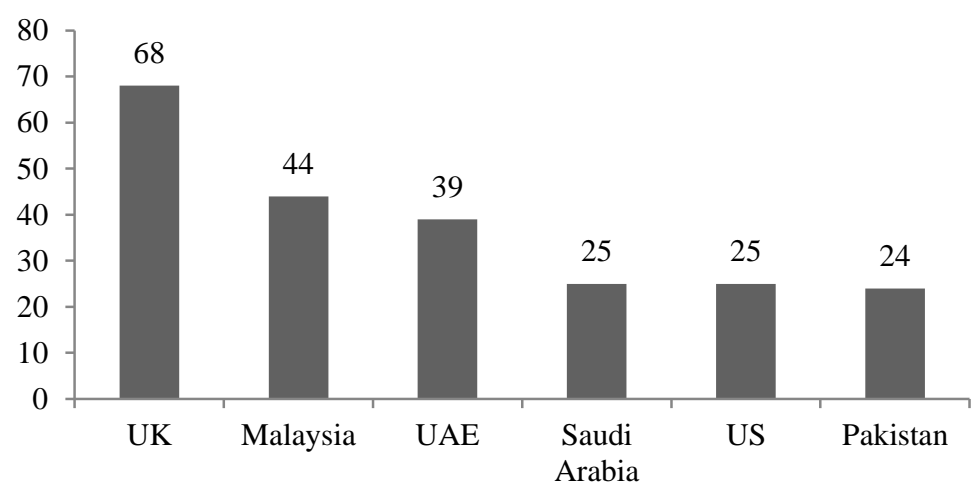

Fig. 3. Number of educational institutions by country [9].

Luxembourg is the birthplace of Islamic Finance in Europe, since it was here that the first Islamic Bank in the West was opened in 1978. The headquarters of the international financial group Daral-Malal-Islami is located in Geneva.

Major European banks such as ABN AMRO, Societe Generate, and JP Morgan Chase have Islamic financial Windows. Islamic mortgages appeared in Europe in the summer of 2003, when two major banks, HSBC and United National Bank, began issuing Islamic mortgage loans in the UK.American Bank Citibank has been cooperating with Islamic financial organizations for a long time, offering Islamic financial products and investing about 1 billion in Islamic financial funds. In 1997, Citibank opened an investment Bank in Bahrain with an authorized capital of \$ 20 million. Currently, the capitalization of more than 250 Islamic financial organizations is about $\$ 15$ billion. The value of assets of Islamic banks is 262 billion, investments in financial instruments-more than 40 billion dollars, deposits in banks-more than 200 billion dollars. The increase in assets of Islamic banks is $10-20 \%$ from 2005 to $2015[11]$.

As a result, 39 countries already provide Islamic banking products and services (operations). This means that the Islamic credit and Finance industry accounts for more than $40-50 \%$ of all savings of Muslim residents worldwide over a period of 8 to 10 years.

The total amount of insurance premiums paid by the 58 largest Islamic insurers is estimated at approximately two billion dollars. This suggests that the insurance market in the Middle East region is growing in the spectrum of $15-20 \%$ per year [12]. The Islamic Development Bank Infrastructure Fund has attempted to create the world's first Shariacompliant global insurance company (GTC), with its parent company in Brunei, with a market capitalization of \$250-300 million.

What are the reasons for such an dynamic development and expansion of Islamic finance? Firstly, the demand from the dynamically increasing number of Muslims in the USA and Europe for financial services and transactions made in accordance with Sharia principles is constantly growing. In latest years, adherence to Islam in Europe and America is constantly growing. So, only in the last 5-10 years, 18,729 Christians living in Europe converted to Islam. Among them, $38 \%$ are women, $24 \%$ are entrepreneurs, $8 \%$ are university graduates, $19 \%$ are students, $3 \%$ are priests, and $8 \%$ are jobless. According to forecasts, over the next decades, with a small rise in the local population of Europe, a further growth in the number of Muslims is expected Secondly, ever-increasing oil prices on world markets increase the attractiveness of investment in the oil industry of the Gulf countries [13].

Kazakhstan plays a fundamental role in the development of Islamic banking at the legislative level, as well as in the promotion of Islamic finance in the Commonwealth of 
Independent States and Central Asia. In 2009, for the first time in the CIS, legislation on Islamic banking was developed and the legal framework for the development of this industry was established. In 2011, the legislative acts of Kazakhstan in the field of Islamic finance began to improve further and created the legal basis for issuing sukuk [14].

At present, there are two Islamic banks in our country; Al-Khilal Bank and Zaman Bank, as well as the Islamic Investment Fund, Takaful is a company specializing in providing financial and consulting services according to Sharia principles. The Association of Islamic Finance Development (ARIF) legal entities association has also appeared in Kazakhstan, which carries out activities to develop the Islamic financial market in Kazakhstan, which brings together the country's financial market entities and represents their interests to government bodies and society as a whole.

After the adoption of the Law on the Organization and Activities of Islamic Banks and Islamic Finance dated February 12, 2009, the necessary organizational infrastructure for the introduction of Islamic finance began to form in the Kazakhstan financial market. To date, the following organizations have been created and are functioning, whose activities comply with the principles of Sharia and Islamic finance:

1) brokerage company (JSC "Fattah Finance");

2) consulting companies (Kausar Consulting Kazakhstan LLP, Akyl-kenes Consulting LLP, Islamic Financial Instruments LLP);

3) investment fund (Joint-stock fund of risky investment "Islamic Fund of Aman");

4) insurance company (Mutual Insurance Company Halal Insurance Takaful JSC);

5) self-regulatory organizations (Association of Legal Entities "Islamic Finance Development Association");

6) public associations (Islamic Center for Finance, Education and Business in Almaty, Club for the Development and Promotion of Islamic Insurance in Kazakhstan).

Over the last year, the total share of Islamic banks in the assets of commercial banks of the Republic of Kazakhstan increased from $0.17 \%$ to $0.21 \%$. At the end of January 2019 , the

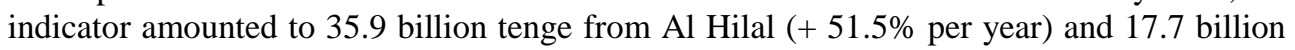
tenge from Zaman-Bank (+ $15.7 \%$ per year).

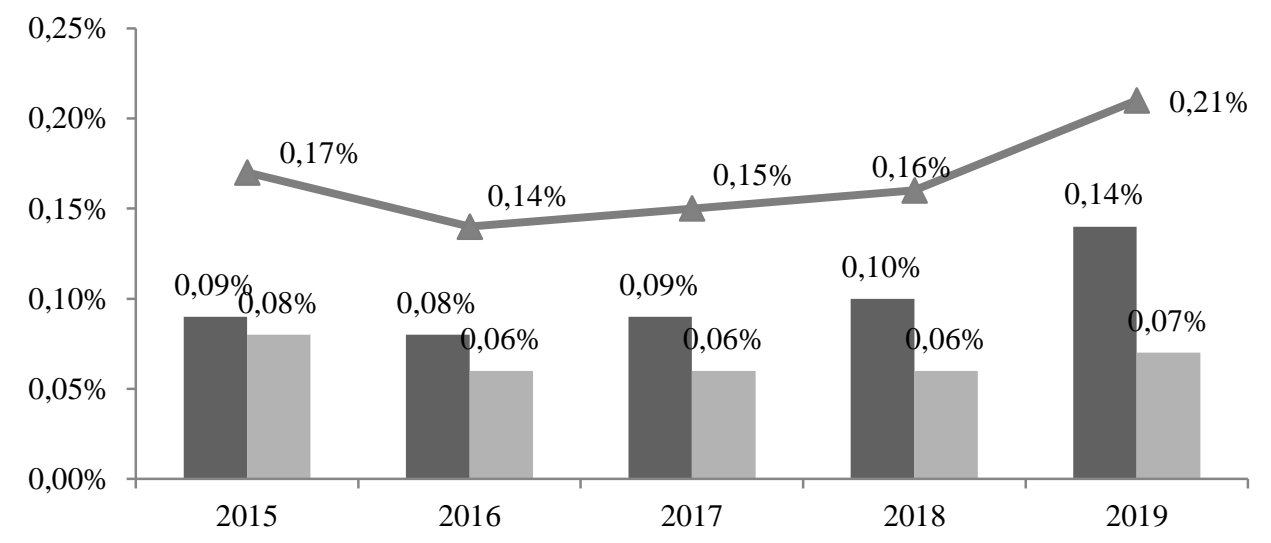

Al-Hilal bank $\longleftarrow$ Zaman bank $\longrightarrow$ Share from total banking sector assets

Note: created on the basis of the author's calculations based on official information of the National Bank of the Republic of Kazakhstan and official websites of Al Hilal and Zaman Bank

Fig. 4. Dynamic of Islamic banks' assets [15]. 
From the analysis bellow and interpretation of results it could be concluded that for Kazakhstan financial and social system the loyal and flexible model of development of Islamic finance is more useful for different reasons. First of all, despite the fact that ethnically most population of our country is Muslim, but really few number of population use all Islam principles in daily life and interest is considered as convenient financial indicator, not as a Riba [16].

Secondly, there are some difficulties in high requirements of establishing full-fledged Islamic banks and as a result there have been established only 2 banks for period of more than 10 years and 1 of them is totally foreign bank. By using Islamic windows system there would be possible to improve and rise the number of financial institution which could provide Islamic finance tools.

Thirdly, for developing supply of the tools of Islamic finance it is important to improve the financial literacy of population in Islamic finance by demonstrating advantages of the products. And in this case Malaysian and UK experiences are also useful, because these two countries have the strong business schools in Islamic finance and market.

\section{Conclusion}

International experience of the development of Islamic finance has huge importance for the further development and improvement of Islamic finance in Kazakhstan.

There are number of recommendations that concluded by the authors during study of foreign experience of implementation Islamic finance:

- improvement the ways to the attraction of population's savings in the Islamic banks, by introducing school banking, so that they do not face a liquidity squeeze, and the young generation is introduced to Islamic banking;

- improvement of the legal framework using international experience and amendments to the tax code to avoid double taxation;

- expanding the range of Islamic finance tools offered to consumers;

- to start actively to develop the retail Islamic Finance, as Islamic Finance repairs proposed major corporate sector;

- using Malaysian and British experience of rapid development of Islamic Finance, consider the introduction of Islamic Windows.

For the financial system of Kazakhstan, affected by the crisis, the attraction and development of Islamic Finance is very important and promising. It is also should be noting that there is the potential role of Islamic Finance in helping to solve a number of state economic problems such as financial support for small and medium-sized businesses, the expansion of the list of services provided by the financial sector, the development of programs of the halal industry, the introduction of new educational programs.

\section{References}

1. Standard\&Poors Global ratings, Islamic finance outlook (2018)

2. CIBAFI, Global Islamic Bankers'survey 2018: evaluating future Impacts, strategic thinking, branding and financial technologies (2018)

3. M. Hassan, J. Dridi, International Monetary Fund, 201 (2010)

4. R. Wilson, The development of Islamic finance in the GCC (2009)

5. Bank Negara Malaysia, Islamic financil services board. Islamic financial services industry stability report, 93 (2018)

6. S. Harvey, Islamic Finance (2015) 
7. Wayne Bvans British Embassy Bishkek. https://assets.publishing.service.gov.uk/government/uploads/system/uploads/attachmen t data/file/503491/2015047_Is Fin_A5_AW ENG_WEB.pdf (2015)

8. M. Ainley, A. Mashayekhi, R. Hicks, A. Rahman, A. Ravalia, The Financial Services Authority (FSA) (2007)

9. TheCityUK annual report. https://www.islamicfinance.com/wpcontent/uploads/2015/11/TheCityUK-Islamic-Finance-2015-report.pdf (2017)

10. I. El Kanj, master tithes in Economic and International Finance, university of Cattolica Del Sacro Cuore, College of Economic Milano (2012)

11. Global Islamic Finance Report Published by Edbiz Corporation, 48 (2018)

12. I. Tlemsani, Journal of Modern accounting and Auditing, 11, 596 (2015)

13. F. di Mauro, C. Pierluigi, S. Couderc, A. Di Maria, S. Masciantonio, S. Ongena, S. Zaher, European central bank, 29 (2013)

14. R. Sagiyeva, L. Kuanova. The Journal of Economic Research \& Business Administration, 127(1), 56 (2019)

15. Official website of National Bank of Republic of Kazakhstan https://nationalbank.kz/?\&switch=russian

16. Mukhtarova, K., Ziyadin, S., Kupeshova, S. \& Doszhan, R. Economic Annals-XXI, 168(11-12), 38-43 (4) (2017). 